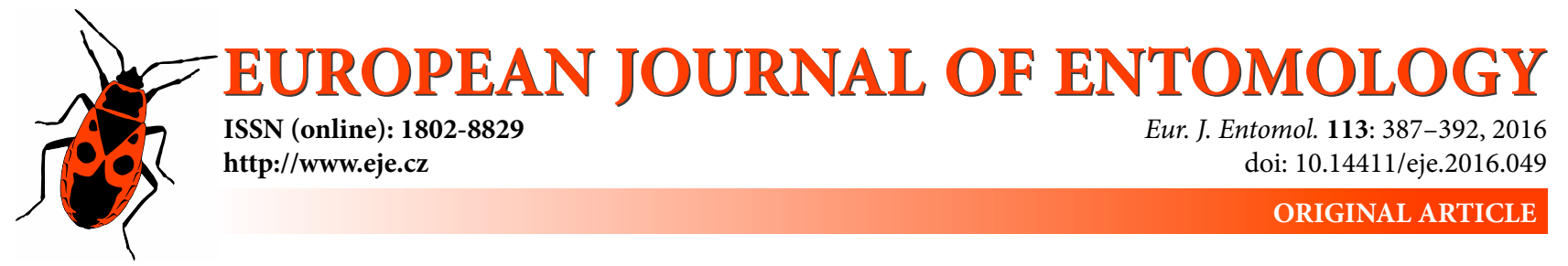

\title{
Comparison of growth parameters of the predator, Chrysoperla nipponensis-B (Neuroptera: Chrysopidae) reared on a diet of eggs of Corcyra cephalonica (Lepidoptera: Pyralidae) and an artificial diet containing ginger
}

\author{
Shafique A. MEMON ${ }^{1}$, Dzolkhifli OMAR ${ }^{1}$, Rita MUHAMAD ${ }^{1}$, Ahamd S. SAJAP ${ }^{2}$, Norhayu ASIB ${ }^{1}$ and Arfan A. GILAL ${ }^{3}$ \\ ${ }^{1}$ Department of Plant Protection, Faculty of Agriculture, Universiti Putra Malaysia, Serdang 43300, Malaysia; \\ e-mails: ahmedshafique89@yahoo.com, zolkifli@upm.edu.my, rita@upm.edu.my, norhayuasib@gmail.com \\ 2 Department of Forest Management, Faculty of Forestry, Universiti Putra Malaysia, Serdang 43300, Malaysia; \\ e-mail: ahsaid@upm.edu.my \\ ${ }^{3}$ Department of Entomology, Faculty of Crop Protection, Sindh Agriculture University Tandojam, Pakistan; \\ e-mail: irfan_gilal@yahoo.com
}

Key words. Neuroptera, Chrysopidae, green lacewing, Chrysoperla nipponensis, life table, fecundity table, artificial diet, natural diet

\begin{abstract}
The growth parameters of the green lacewing, Chrysoperla nipponensis-B (Okamoto), were studied under laboratory conditions. The highest mortality was recorded in the immature stages (instars $1^{\text {st }}, 2^{\text {nd }}, 3^{\text {rd }}$ and pupae) of $C$. nipponensis fed on the eggs of Corcyra cephalonica (37.26\%). The sex ratios (proportion of female to male) when reared on the eggs of $C$. cephalonica and an artificial diet with ginger were $0.93: 1.00$ and $0.87: 1.00$, respectively. The maximum life spans of females reared on the eggs of $C$. cephalonica and an artificial diet with ginger were 63 and 64 days, respectively. The females reared on the eggs of $C$. cephalonica produced the highest number of eggs (10.4) on the fifth day of oviposition, whereas on the artificial diet with ginger it was 9.26 on the eighth day of oviposition. The net reproductive rate (Ro) and maximum gross reproductive rate (GRR) of $C$. nipponensis fed on the eggs of $C$. cephalonica were 69.50 and 223.10 females per female per generation, respectively, whereas for the artificial diet with ginger they were 117.24 and 236.89 females per female per generation, respectively. Mean generation time (T) was 37.06 and 48.16 for the eggs of $C$. cephalonica and artificial diet with ginger, respectively. The intrinsic rate of natural increase ( $r$ ) was 0.11 and 0.09 females per female per day for the eggs of $C$. cephalonica and artificial diet with ginger, respectively. The finite rate of increase $(\lambda)$ was 1.12 and 1.11 females per female per day for the eggs of $C$. cephalonica and artificial diet with ginger, respectively. The population doubling time (DT) was 6.05 days on the diet of eggs of $C$. cephalonica and 7.00 on the artificial diet with ginger.
\end{abstract}

\section{INTRODUCTION}

Green lacewings are important predatory biological control agents that can be used in biological control programs (Gautam, 1994; Venkatsan et al., 2008). Chrysoperla (carnea-group) and Mallada desjardinsi (Navas) are well recognized and widely distributed green lacewing species in India, Europe, USSR, North America, South America and Central Africa. The green lacewings, Chrysoperla spp. (Neuroptera: Chrysopidae) are cosmopolitan predators that occur in a wide range of agricultural habitats. The larvae of Chrysoperla spp. are voracious and efficient biological control agents of various phytophagous arthropods such as aphids, caterpillars, leafhoppers, whiteflies, thrips and insect eggs (McEwen et al., 2001; Carrillo \& Elanov, 2004). It is estimated that up to one third of the successful biological insect pest control programs are attributed to the introduction of Chrysoperla carnea (Williamson \& Smith, 1994). Chrysoperla spp. are easily mass reared in the laboratory on their natural prey for augmentative use against many insect pests (Syed et al., 2008). However, continuous maintenance of host populations for the mass rearing of Chrysoperla spp. is very difficult and expensive, which necessitates the development of alternative methods for their mass production. Many artificial diets have been evaluated for rearing Chrysoperla spp. with varying success (Vanderzant, 1969; Yazlovetsky, 1992; Cohen \& Smith, 1998; Zhang et al., 2004). These artificial diets mostly contain beef, hen eggs, yeast, honey, sucrose, vitamins, minerals, propionate, potassium sorbate, streptomycin sulfate and chlortetracycline, and most are costly (Yazlovetsky, 1992; Cohen \& Smith, 1998; Sattar et al., 2007). This resulted in the development of a cost effective artificial diet for 
the mass rearing of Chrysoperla nipponensis-B, which includes ginger.

There are several studies on the life table parameters of Chrysoperla spp. reared on natural prey as life tables are one of the most important tools in entomological research (Win et al., 2009). Cohort life table provide a comprehensive description of the survivorship, development and reproduction of a population, which are fundamental factors in both theoretical and applied population ecology (Taghizadeh et al., 2008). Moreover, there are no comparative life table studies of $C$. nipponensis reared on different diets in Malaysia. Therefore, this study was conducted to determine the growth parameters of $C$. nipponensis reared on the eggs of Corcyra cephalonica and an artificial diet that included ginger, with the view of improving the mass and quality production of $C$. nipponensis for use against insect pests.

\section{MATERIALS AND METHODS}

\section{Rearing of $C$. nipponensis on the eggs of Corcyra cephalonica}

Chrysoperla nipponensis adults were reared in rectangular cages $37 \times 28 \times 22 \mathrm{~cm}$ in size. Adults were supplied with an artificial standard diet consisting of yeast, sugar, honey, casein and distilled water. Wet cotton was provided in glass vials as a source of water. For the oviposition of females, a black organza cloth was placed on top of the cage and the eggs deposited on this cloth were removed daily. The larvae from the eggs were then reared on the eggs of Corcyra cephalonica. The eggs of C. cephalonica were spread on a sterilized mixture of maize, rice, whea and semolina $(1: 1: 1: 1)$ on which they developed up to the adult stage and were then collected for mating in a plastic cage. The eggs laid by these adults were then collected and killed by placing them in a freezer before being used to rear C. nipponensis larvae.

\section{Composition of the artificial diet for larvae}

The artificial diet for the larvae consisted of $100 \mathrm{~g}$ ground beef (with $25 \%$ fat), $100 \mathrm{~g}$ ground beef liver, $15 \mathrm{~g}$ sucrose, $100 \mathrm{~g}$ hen eggs, $10 \mathrm{ml}$ distilled water, $20 \mathrm{~g}$ honey $(5 \mathrm{~g}$ dissolved in $15 \mathrm{ml}$ of water), $14 \mathrm{~g}$ brewer's yeast, $5 \mathrm{ml}$ acetic acid, $0.5 \mathrm{~g}$ potassium sorbate, $0.5 \mathrm{~g}$ ginger and $5 \mathrm{ml}$ vitamin solution. All the ingredients used were weighed carefully using a Digital Analytical Balance (Sartorious, BT-224S, Germany). The ground beef and ground beef liver were cut into small pieces using a knife and were kept in a refrigerator for $24 \mathrm{~h}$. The mixture of meat, honey, water, ginger and brewer's yeast were blended in a food processor (Panasonic, MK-5087M, Japan). In a beaker, $20 \mathrm{ml}$ of water was heated to 80 to $90^{\circ} \mathrm{C}$ on a hot plate (IKA-COMBIMAG RCT 31197, China) and $15 \mathrm{~g}$ sucrose, $5 \mathrm{ml}$ of acetic acid and potassium sorbate were added and stirred using a magnetic stirrer. Then, $100 \mathrm{~g}$ of blended eggs were added. All ingredients were blended (BRAUN, ZK-200, Germany) for 5 to 6 min until the entire mixture had a stringy paste-like consistency. The diet was then fed to the larvae in trays that are used in ELISA tests.

\section{Life table experiments}

The life table of $C$. nipponensis was constructed using data obtained when the larvae were fed $C$. cephalonica eggs and the above artificial diet at $25 \pm 2{ }^{\circ} \mathrm{C}, 55-85 \% \mathrm{RH}$ and a $12 \mathrm{~L}: 12 \mathrm{D}$ photoperiod. Three separate groups of 148 (cohort 1), 123 (cohort 2) and 106 (cohort 3) freshly laid eggs of C. nipponensis, were used to construct life tables for individuals reared on these two diets. The eggs were placed individually in the cells of ELISA trays to prevent cannibalism. The larvae of the different cohorts of eggs were fed either frozen eggs of $C$. cephalonica or the artificial diet with ginger. The diets were changed every two days, when $1.5 \mathrm{~g}$ of both diets were provided. Daily records of the survival and development of the larvae were kept until the adults emerged. After the emergence of the adults, they were transferred to an oviposition cage and provided with a standard adult diet. The fecundity and mortality were recorded daily until the last adult died. Construction of the life table was done following the procedures described by Birch (1948) and Southwood (1978).

The life table and fecundity schedule were constructed using the following parameters:

\section{Life table}

$\mathrm{X}$ : The pivotal age for the age class in units of time (days).

lx: The number of surviving individuals at the beginning of age class $x$.

Lx: The number of individuals alive between age class $\mathrm{x}$ and $\mathrm{x}+1$.

Tx: Total number of individuals beyond age class $\mathrm{x}$.

$\mathrm{dx}$ : The number of individual dying during age interval $\mathrm{x}$.

ex: The expectation of life remaining for individuals of age class $\mathrm{x}$.

RM\%: Percentage of real mortality calculated based on the population density at the beginning of the generation.

$\mathrm{RM}=(\mathrm{dx} / \mathrm{lo}) 100$.

IM\%: Indispensable (irreplaceable) mortality, which is the portion of generation mortality that would not occur if the apparent mortality (qx) of an age interval was removed from the life system. It is assumed that the subsequent mortality factors will destroy the same percentage of the population independent of any change in population density.

\section{Fecundity schedule}

$\mathrm{X}$ : The pivotal age for the age class in units of time (days).

$1 \mathrm{x}$ : The number of females surviving at the beginning of age class $\mathrm{x}$ (given as a fraction of 1.0).

$m x$ : The number of female eggs laid by age class $x$.

lxmx: Total number of female eggs laid by age class $\mathrm{x}$.

Ro: Net reproductive rate. It is equal to the sum of $1 x m x$ or Ro $=\Sigma 1 \mathrm{xmx}$.

$\mathrm{T}$ : Cohort generation time (in days), approximated by $\mathrm{T}=\Sigma$ $\mathrm{Xlxmx} / \Sigma 1 \mathrm{xmx}$.

$r$ : Innate capacity for increase, calculated using $\mathrm{rc}=\ln \mathrm{Ro} / \mathrm{Tc}$. $\mathrm{rm}$ : The maximum population growth, the innate capacity for increase, calculated by iteration of Euler's equation, $\Sigma$ e-r.x lxmx.

$\lambda$ : Finite rate of increase, number of female offspring per female per day, calculated using, $\lambda=$ er.

DT: Doubling time, the number of days required by a population to double, calculated using, DT $=\ln 2 / \mathrm{r}$.

b: Intrinsic birth rate, $1 / \Sigma \mathrm{e}-$ r.xIx.

$\mathrm{d}$ : Intrinsic death rate, $\mathrm{b}-\mathrm{rm}$.

GRR: Gross reproduction rate calculated using $\Sigma \mathrm{mx}$.

The population parameters of the life and fecundity tables were constructed separately for $C$. nipponensis reared on both diets based on 3 cohorts for each diet. Moreover, comparison between life parameters of $C$. nipponensis reared on the diet with ginger and the eggs of $C$. cephalonica were statistically compared using Student $\mathrm{t}$-test and presented as Mean $\pm \mathrm{SE}$.

\section{RESULTS AND DISCUSSION}

\section{Age-specific survival life table}

Fig. 1 shows the patterns in survivorship curves (lx) for six cohorts of $C$. nipponensis reared on eggs of C. cepha- 

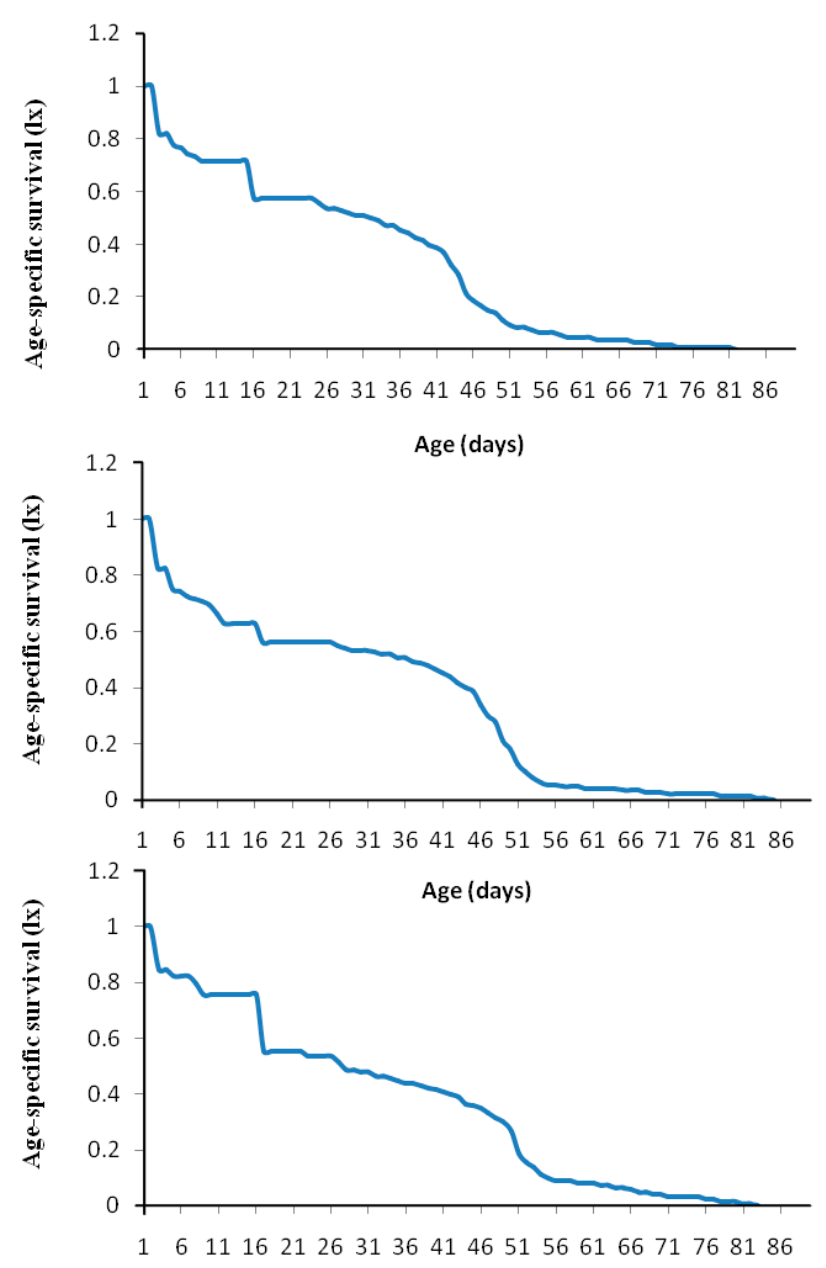

Age (days)
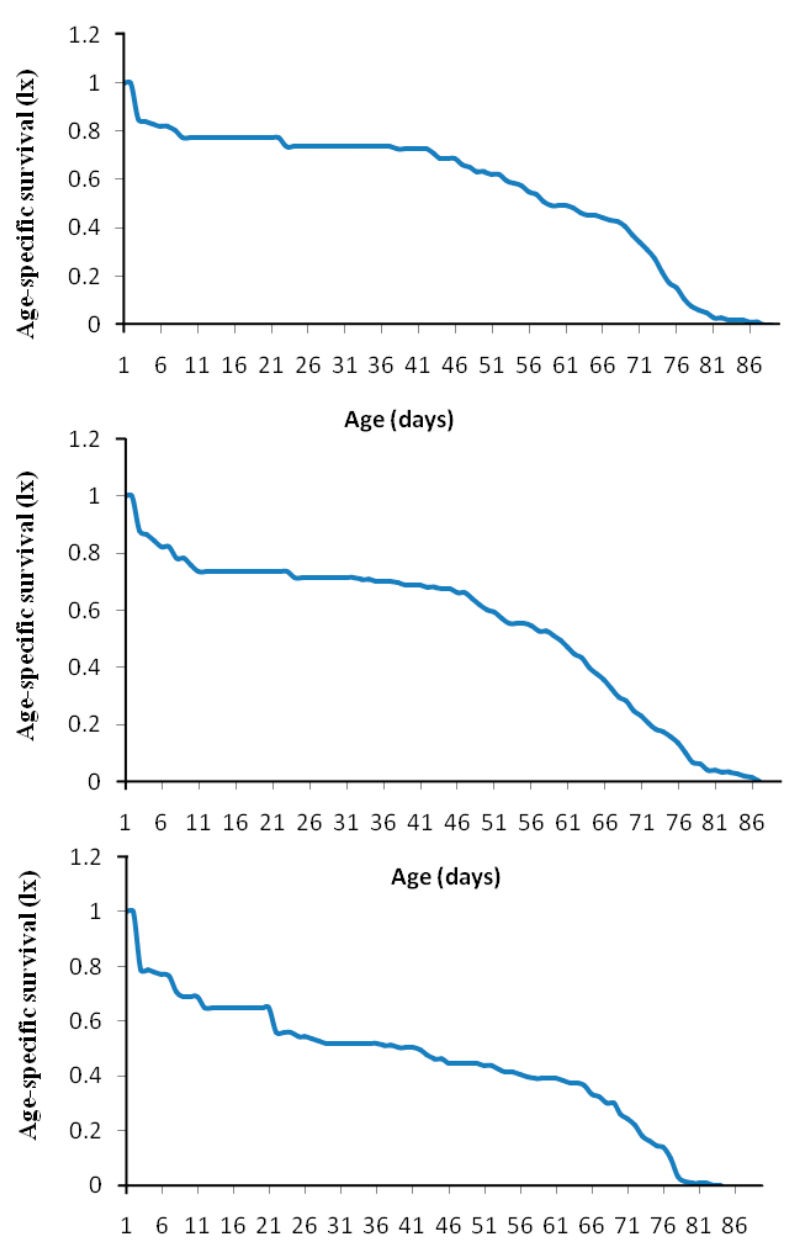

Age (days)

Fig. 1. The survivorship curves (Ix) of $C$. nipponensis reared on the eggs of $C$. cephalonica (left) and an artificial diet with ginger (right).

lonica and an artificial diet with ginger. Fig. 1 indicates that during the life span of the predator, there was a high mortality of those reared on the eggs of $C$. cephalonica during the egg, $2^{\text {nd }}$ instar larval and pupal stages. However, those reared on the artificial diet with ginger suffered a high mortality during the egg, $1^{\text {st }}$ instar larval and pupal stages. Green lacewings are highly sensitive to changes in temperature and water availability, which affects the growth and survival of these predators (Schowalter, 2006). The first emergence of adults reared on eggs of $C$. cephalonica and artificial diets with ginger occurred on day 21, 22 and 22, and day 26, 24 and 24 for cohorts 1, 2, and 3, respectively. The maximum life span of $C$. nipponensis reared on artificial diet with ginger and eggs of $C$. cephalonica were recorded at 88 and 85 days, respectively. The survivorship curves are of type III based on the classification of Pearl (1928), Speight et al. (1999) and Schowalter (2006).

\section{Mortality of immature stages of $\boldsymbol{C}$. nipponensis}

The age specific mortality of the immature stages of $C$. nipponensis, reared on eggs of $C$. cephalonica and the artificial diet with ginger is shown in Table 1. All larvae underwent three larval molts before transforming into pupae. The highest mortality of $C$. nipponensis reared on both diets were recorded in the pupal (19.08 and 6.64, respectively) followed by $2^{\text {nd }}$ instar larval stage ( 7.39 and 3.89 ,

Table 1. Life table of green lacewing C. nipponensis reared on an artificial diet with ginger (Art. diet) and on the eggs of $C$. cephalonica (Nat. diet).

\begin{tabular}{|c|c|c|c|c|c|c|c|c|c|c|c|c|c|c|c|c|}
\hline \multirow{2}{*}{$\begin{array}{l}\text { Age } \\
\text { (days) }\end{array}$} & \multicolumn{2}{|c|}{$I_{x}$} & \multicolumn{2}{|c|}{$L_{x}$} & \multicolumn{2}{|c|}{$d_{x}$} & \multicolumn{2}{|c|}{$100 q_{x}$} & \multicolumn{2}{|c|}{$\mathrm{S}_{\mathrm{x}}$} & \multicolumn{2}{|c|}{$T_{x}$} & \multicolumn{2}{|c|}{$e_{x}$} & \multicolumn{2}{|c|}{ K-value } \\
\hline & $\begin{array}{l}\text { Art. } \\
\text { diet }\end{array}$ & $\begin{array}{l}\text { Nat. } \\
\text { diet }\end{array}$ & $\begin{array}{l}\text { Art. } \\
\text { diet }\end{array}$ & $\begin{array}{l}\text { Nat. } \\
\text { diet }\end{array}$ & $\begin{array}{l}\text { Art. } \\
\text { diet }\end{array}$ & $\begin{array}{l}\text { Nat. } \\
\text { diet }\end{array}$ & $\begin{array}{l}\text { Art. } \\
\text { diet }\end{array}$ & $\begin{array}{l}\text { Nat. } \\
\text { diet }\end{array}$ & $\begin{array}{l}\text { Art. } \\
\text { diet }\end{array}$ & $\begin{array}{l}\text { Nat. } \\
\text { diet }\end{array}$ & $\begin{array}{l}\text { Art. } \\
\text { diet }\end{array}$ & $\begin{array}{l}\text { Nat. } \\
\text { diet }\end{array}$ & $\begin{array}{l}\text { Art. } \\
\text { diet }\end{array}$ & $\begin{array}{l}\text { Nat. } \\
\text { diet }\end{array}$ & $\begin{array}{l}\text { Art. } \\
\text { diet }\end{array}$ & $\begin{array}{l}\text { Nat. } \\
\text { diet }\end{array}$ \\
\hline ggs & 377 & 377 & 347.00 & 347.00 & 60 & 60 & 15.92 & 15.92 & 84.08 & 84.08 & $1,773.00$ & $1,715.00$ & 5.11 & 4.94 & 0.08 & 0.08 \\
\hline nstar 1 & 317 & 317 & 300.00 & 300.50 & 34 & 33 & 10.73 & 10.41 & 89.27 & 89.59 & $1,396.00$ & $1,338.00$ & 4.65 & 4.45 & 0.05 & 0.05 \\
\hline רstar 2 & 283 & 284 & 277.50 & 273.50 & 11 & 21 & 3.89 & 7.39 & 96.11 & 92.61 & $1,079.00$ & $1,021.00$ & 3.89 & 3.73 & 0.02 & 0.03 \\
\hline nstar 3 & 272 & 263 & 265.33 & 245.67 & 1 & 1 & 0.37 & 0.38 & 99.63 & 99.62 & 796.00 & 737.00 & 3.00 & 3.00 & 0.00 & 0.00 \\
\hline upa & 271 & 262 & 262.00 & 237.00 & 18 & 50 & 6.64 & 19.08 & 93.36 & 80.92 & 524.00 & 474.00 & 2.00 & 2.00 & 0.03 & 0.09 \\
\hline Adult & 253 & 212 & 126.50 & 106.00 & 253 & 212 & & & & & & & & & & \\
\hline
\end{tabular}




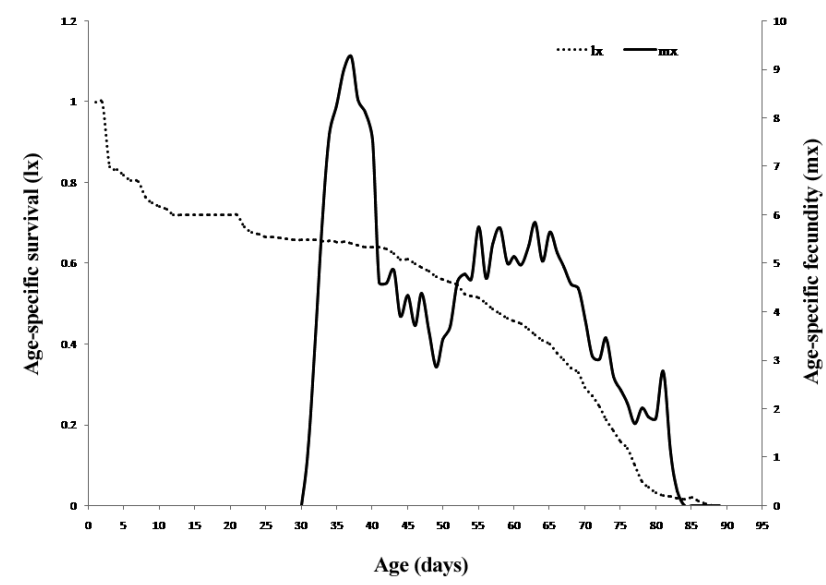

Fig. 2. Life and age-specific fecundity of $C$. nipponensis reared on the artificial diet with ginger.

respectively). Overall, the total mortality in the immature stages $\left(1^{\text {st }}, 2^{\text {nd }}, 3^{\text {rd }}\right.$ and pupae $)$ of $C$. nipponensis reared on eggs of $C$. cephalonica was $37.26 \%$, which is higher than that recorded on the artificial diet with ginger $(21.62 \%)$. The total number of adults that emerged from the artificial diet with ginger was higher (118 females : 134 males) than emerged from those reared on eggs of C. cephalonica $(103$ females : 109 males). The female to male sex ratio recorded for the artificial diet with ginger was $0.87: 1.00$ and that for those reared on eggs of C. cephalonica was $0.93: 1.00$. Studies on another lacewing species, Mallada bioninensis (Okamoto) also indicate a significant effect of diet on the mortality of the different stages (Shivankar \& Singh, 1998; Nehrae et al., 2004; Elsiddig et al., 2006). The high mortality of the immature stages of various species of lacewings is also reported by Alasady et al. (2010) for Apertochrysa sp. and Gautam et al. (2009) for Chrysoperla sp. and Mallada desjardinsi (Navas).

\section{Age-specific fertility schedule}

Age-specific survivorship $\left(1_{\mathrm{x}}\right)$ and fecundity $\left(\mathrm{m}_{\mathrm{x}}\right)$ of $C$. nipponensis are shown in Figs 2 and 3. For those reared on the artificial diet with ginger and eggs of $C$. cephalonica, the first adult female emerged on day 25 and 21 , whereas, the death of last female reared on artificial diet with ginger and eggs of C. cephalonica was recorded on day 88 and 85 , respectively. The maximum life span of females

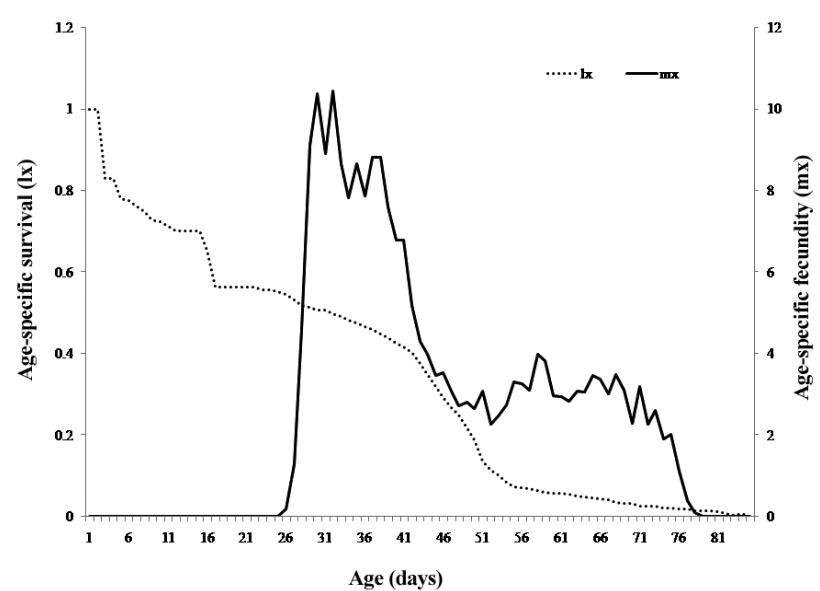

Fig. 3. Life and age-specific fecundity of $C$. nipponensis reared on the eggs of $C$. cephalonica.

reared on eggs of $C$. cephalonica and an artificial diet with ginger were 63 and 64 days, respectively that is similar to that reported in several previous studies, which show that the longevity of lacewings depends on the food available to the adults and the diet the larval stages were fed on (Joshi \& Yadav, 1990; Nehrae et al., 2004; Senthil Kumar $\&$ Gautam, 2007). Females reared on the artificial diet with ginger started egg laying on day 30, or 5 days after emergence, whereas those reared on eggs of $C$. cephalonica, started laying eggs on day 26, or 5 days after emergence. The highest number of eggs produced per female reared on the artificial diet with ginger was 9.26 on the fourth day of oviposition, whereas on the eggs of $C$. cephalonica, it was 10.4 on the fifth day of oviposition. Insect fecundity and life span are both influenced by the quality of the food (Siswanto et al., 2008).

Table 2 summarizes the population and reproductive parameters of $C$. nipponensis. Maximum mean generation time $(\mathrm{T})$ of the individuals reared on the artificial diet with ginger was $42.19 \pm 0.12$ days compared to the 37.06 \pm 0.15 days for those reared on eggs of $C$. cephalonica. The intrinsic rate of natural increase ( $r$ ) recorded for those reared on the artificial diet with ginger was $0.11 \pm 0.01$ and on the eggs of $C$. cephalonica (natural) $0.12 \pm 0.01$ females per female per day. Jervis et al. (2005) also report that prey species can influence the intrinsic rate of natural

Table 2. Population and reproductive parameters of $C$. nipponensis reared on the eggs of $C$. cephalonica (natural diet) and the artificial diet with ginger (artificial diet) (Mean \pm S.E).

\begin{tabular}{|c|c|c|c|c|}
\hline \multirow{2}{*}{ No. } & \multirow{2}{*}{ Parameters } & \multirow{2}{*}{ Formula } & \multicolumn{2}{|c|}{ Values } \\
\hline & & & Artificial diet $(n=118)$ & Natural diet $(n=101)$ \\
\hline 1 & Approximate generation time $\left(\mathrm{T}_{\mathrm{c}}\right)$, (days) & $\sum \mathrm{I}_{\mathrm{x}} \mathrm{m}_{\mathrm{x}} \mathrm{x} / \sum_{\mathrm{x}} \mathrm{m}_{\mathrm{x}}$ & $48.16 \pm 0.15 a$ & $37.06 \pm 0.15 b$ \\
\hline 2 & Corrected generation time $(\mathrm{T})$, (days) & $\ln R_{0} / r_{m}$ & $42.19 \pm 0.12 a$ & $37.06 \pm 0.15 b$ \\
\hline 3 & Innate capacity for increase $\left(r_{c}\right)$ & In Ro / Tc & $0.09 \pm 0.01 b$ & $0.11 \pm 0.01 a$ \\
\hline 4 & Intrinsic rate of increase $\left(r_{m}\right)$ & $\sum e_{m}^{-r} \times I_{x} m_{x}=1$ & $0.11 \pm 0.01 a$ & $0.12 \pm 0.01 a$ \\
\hline 5 & Finite rate of increase $(\lambda)$ & $\mathrm{e}^{r}$ & $1.11 \pm 0.02 a$ & $1.12 \pm 0.02 a$ \\
\hline 6 & Doubling time (DT), (days) & $\ln 2 / r$ & $7.00 \pm 0.03 a$ & $6.05 \pm 0.02 b$ \\
\hline 7 & Gross reproduction rate & $\sum m_{x}$ & $236.89 \pm 1.53 a$ & $223.1 \pm 1.41 b$ \\
\hline 8 & Net reproduction rate (Ro) & $\sum \mathrm{l}_{\mathrm{x}} \mathrm{m}_{\mathrm{x}}$ & $117.24 \pm 0.90 a$ & $69.5 \pm 0.82 b$ \\
\hline
\end{tabular}

Means followed by same letters within rows are not significantly different $(P>0.05)$. 
increase of predators. The finite rates of increase $(\lambda)$ for those reared on the artificial diet with ginger and eggs of C. cephalonica were $1.11 \pm 0.02$ and $1.12 \pm 0.02$ females per female per day, respectively. These results are in accordance with Jokar et al. (2012) who record a finite rate of increase $(\lambda)$ of $1.17 \pm 0.001$ and $1.20 \pm 0.002$ for $C$. carnea fed on Anagasta kuehniella and a semi-artificial diet, respectively. The doubling time (DT) of the predator reared on the eggs of $C$. cephalonica was $6.05 \pm 0.02$ days, which is less than when reared on the artificial diet with ginger ( $7.00 \pm 0.03$ days). Studies show that $r$, T, and DT are useful indices of population growth of insects under a given set of conditions (Siswanto et al., 2008). Moreover, C. nipponensis reared on the eggs of $C$. cephalonica had a lower reproductive performance than those reared on the articial diet with ginger. The superior performance of the C. nipponensis reared on the artificial diet with ginger in terms of several biological parameters may be due to the addition of ginger that not only enhances its active predatory period but also its searching and killing abilities. Natural alternatives to antibiotics, such as ginger, has attracted attention due to its wide range of potential beneficial effects (Manesh et al., 2012). Ginger is used in the preparation of food to impart flavour, colour and food preservation, and also enhances palatability (Polasa \& Nirmala, 2003). The net reproductive rate (Ro) was higher on the artificial diet with ginger (117.24 \pm 0.90 females per female per generation) than on the eggs of C. cephalonica ( $69.50 \pm 0.82$ females per female per generation). The maximum gross reproductive rate (GRR) was $236.89 \pm 1.53$ and $223.10 \pm$ 1.4 females per female per generation for those reared on the artificial diet with ginger and eggs of $C$. cephalonica, respectively. The results are similar to those of Jokar \& Zarabi (2012) who record a GRR of $225.5 \pm 3.45$ and 267.8 \pm 4.8 for $C$. carnea fed A. kuehniella and a semi artificial diet, respectively.

\section{CONCLUSIONS}

This life table study indicates that the survivorship curves of $C$. nipponensis fed on both the eggs of C. cephalonica and an artificial diet with ginger is of type III, which is commonly found in insects. The highest mortality of $C$. nipponensis was recorded in the immature stages $\left(1^{\text {st }}\right.$, $2^{\text {nd }}, 3^{\text {rd }}$ and pupae), which are the weakest stages in its life cycle. Rearing C. nipponensis on an artificial diet with ginger resulted in the largest number of individuals reaching the adult stage. Higher survival and reproductive potential were recorded for $C$. nipponensis reared on the artificial diet with ginger than on the eggs of $C$. cephalonica. Population parameters (GRR, Ro, and T) were also higher on the artificial diet ginger except for the finite rate of increase that was same on both diets. The doubling time (DT) was one day longer on the artificial diet with ginger than on the eggs of $C$. cephalonica. Thus an artificial diet with ginger is more suitable for the mass rearing of $C$. nipponensis than the eggs of $C$. cephalonica, and has an additional advantage of an increased shelf life due to the inclusion of ginger in the diet.
ACKNOWLEDGEMENTS. This research was financially supported by Universiti Putra Malaysia's research grant (number 63236). It is a pleasure to acknowledge all the authors whose meticulous and detailed work was cited in this paper.

\section{REFERENCES}

Alasady M.A.A., Omar D., Ibrahim Y. \& Ibrahim R. 2010: Life table of the green lacewing Apertochrysa sp. (Neuroptera: Chrysopidae) reared on rice moth Corcyra cephalonica (Lepidoptera: Pyralidae). —Int. J. Agric. Biol. 12: 266-270.

BIRCH L.C. 1948: The intrinsic rate of eggs of C. cephalonica increase of an insect population. - J. Anim. Ecol. 17: 15-26.

CARrillo M. \& Elanov P. 2004: The potential of Chrysoperla carnea as a biological control agent of Myzus persicae in glass houses. - Ann. Appl. Biol. 32: 433-439.

Cohen A.C. \& Smith L.K. 1998: A new concept in artificial diets for Chrysoperla rufilabris: the efficacy of solid diets. — Biol. Contr. 13: 49-54.

Elsiddig S.I.Y., Gauta R.D. \& Chander S. 2006: Life table of predator, Mallada boninensis (Okamoto) (Chrysopidae: Neuroptera) on the eggs of Corcyra cephalonica Stainton and larvae of Tribolium castaneum Herb. - J. Entomol. Res. 30: 301-307.

Gautam R.D. 1994: Present status of rearing of chrysopids in India. - Bull. Entomol. 35: 31-39.

Gautam S.U.D., Singh A.K. \& Gautam R.D. 2009: Comparative life table analysis of chrysopids reared on Phenacoccus solenopsis Tinsley in laboratory. - J. Biol. Contr. 23: 393-402.

Jervis M.A., Copland M.J.W. \& Harvey J.A. 2005: The life cycle. In Jervis M.A. (ed.): Insects as Natural Enemies: A Practical Perspective. Springer, Dordrecht, pp. 73-165.

JoKar M. \& Zarabi M. 2012: Prominence of three diets on life table parameters for Chrysoperla carnea (Neuroptera: Chrysopidae) to mass rearing under laboratory conditions. - Arch. Phytopathol. Plant Prot. 45: 2213-2222.

Joshi B.C. \& YADAV D.N. 1990: Biology and feeding potential of Mallada desjardinsi (Okamoto), a chrysopid predator of whitefly, Bemisia tabaci Gennadius. - J. Biol. Contr. 4: 18-21.

MANESH M.K. 2012: Influence of poly germander (Teucrium polium) and watercress (Nasturtium officinale) extract on performance, carcass quality and blood metabolitesof male broilers. - Res. Opin. Anim. Vet. Sci. 2: 69-71.

McEwen P.K., New T.R.R. \& Whittington A. 2001: Lacewings in the Crop Management. Cambridge University Press, 564 pp. Nehrae S.K., Deotale V.Y., Deotale R. \& Dawane P.N. 2004: Biology and predator's potential of Mallada boninensis (Okamoto) against sucking pests. - J. Soils Crops 14: 427-432.

Pearl R. 1928: The Rate of Living. Knopf, New York, 226 pp.

Polasa K. \& Nirmala K. 2003: Ginger: its role in xenobiotic metabolism. - ICMR Bull. 33(6): 57-62.

Sattar M., Fatima B., Ahmed N. \& Abro G.H. 2007: Development of larval artificial diet of Chrysoperla carnea (Stephens) (Neuroptera: Chrysopidae). — Pakistan J. Zool. 39: 103-107.

Schowalter T.D. 2006: Insect Ecology: An Ecosystem Approach. 2nd ed. Academic Press, Tokyo, 572 pp.

Senthil Kumar M. \& Gautam R.D. 2007: Influence of different floral feeds on the biological attributes of Chrysoperla carnea (Stephens). - Ann. Plant Prot. Sci. 15: 4-7.

ShivanKar V.J. \& Singh S. 1998: Management of insect pests in citrus. - Nat. Res. Cent. Citrus Techn. Bull. 3: 99.

Siswanto M.R., Omar D. \& Karmawati E. 2008: Life table and population parameters of Helopeltis antonii (Hemiptera: Miridae) reared on cashew (Anacardium occidentalel). - J. Biosci. 19: 91-101. 
Southwood T.R.E. 1978: Ecological Methods with Particular Reference to the Study of Insect Populations. 2nd ed. Chapman and Hall, London, $524 \mathrm{pp}$.

Speight M.R., Hunter M.D. \& Watt A.D. 1999: Ecology of Insects: Concepts and Applications. Blackwell Sciences, Oxford, $360 \mathrm{pp}$.

Syed A.N., Ashfaq M. \& Ahmad S. 2008: Comparative effect of various diets on development of Chrysoperla carnea (Neuroptera: Chrysopidae). — Int. J. Agric. Biol. 10: 728-730.

Taghizadeh R., Fathipour Y. \& Kamali K. 2008: Influence of temperature on life table parameters of Stethorus gilvifrons (Mulsant) (Coleoptera: Coccinellidae) fed on Tetranychus urticae Koch. - J. Appl. Entomol. 132: 638-645.

VANDERZANT E. 1969: An artificial diet for larvae and adults of Chrysopa carnea, an insect predator of crop pests. - J. Econ. Entomol. 62: 256-257.

Venkatsan T., Poorani J., Jalali S.K., Srinivasamurthy K., Ashok Kumar G., Lalitha Y. \& Rajeshwari R. 2008: Con- firmation of the occurrence of Chrysoperla zastrowi arabica Henry et al. (Neuroptera: Chrysopidae) in India. - J. Biol. Contr. 22: 143-147.

Williamson F.A. \& Smith A. 1994: Biopesticides in Crop Protection. Agrow Report (DS 95), PJB Publications, 120 pp.

Win S.S., Muhamad R., Ahmad Z.A.M. \& Adam N.A. 2009: Life table and population parameter of Sogatella furcifera (Horvath) (Homoptera: Delphacidae) on rice. - J. Biol. Sci. 9: 904-908. YAZLOVETSKY I.G. 1992: Development of artificial diets for entomophagous insects by understanding their nutrition and digestion. In Anderson T.E. \& Leppla N.C. (eds): Advances in Insect Rearing for Research and Pest Management. Westview Press, New Delhi pp. 41-62.

Zhang F., Wang S., Luo C., Chen Y. \& Li F. 2004: Effects of artificial diet and breeding methods on growth and development of Chrysopa septempunctata. - Plant Prot. 30: 36-40.

Received September 11, 2015; revised and accepted February 17, 2016 Published online May 3, 2016 